\title{
PRODUKSI KITIN SKALA PILOT PLANT DARI CANGKANG RAJUNGAN (Portunus spp.)
}

\author{
Sumpeno Putro, Syamdidi, dan Singgih Wibowo*)
}

\begin{abstract}
ABSTRAK
Penelitian ini dimaksudkan untuk mencari konsentrasi $\mathrm{NaOH}$ teknis (technical grade) dan waktu ekstraksi optimum dalam proses pengolahan kitin dari limbah cangkang rajungan (Portunus spp.) skala pilot plant. Beberapa penelitian terdahulu menunjukkan bahwa $\mathrm{NaOH}$ merupakan bahan kimia yang efektif dalam proses deproteinasi cangkang rajungan, namun harganya cukup mahal. Untuk skala besar, maka perlu digunakan $\mathrm{NaOH}$ teknis yang harganya lebih murah. Karena $\mathrm{NaOH}$ teknis mempunyai tingkat kemurnian yang lebih rendah, maka perlu dilakukan penyesuaian konsentrasi yang diperlukan, agar tercapai efiensi usaha, dalam arti kualitas produk terjamin, tetapi biaya produksi dapat ditekan. Berdasarkan hasil penelitian bahwa untuk pembuatan kitin diperlukan $\mathrm{NaOH}$ p.a. (pro analysis grade) sebanyak $3 \%$, penelitian ini didesain dengan menggunakan $\mathrm{NaOH}$ teknis dengan konsentrasi 3,5\%,5\% dan 6,5\% dan waktu perendaman 2 dan 3 jam. Hasil penelitian skala pilot plant ini menunjukkan bahwa penggunaan $\mathrm{NaOH}$ teknis dengan konsentrasi $3,5 \%, 5 \%$ dan $6,5 \%$ dan waktu perendaman selama 2 dan 3 jam tidak berpengaruh nyata terhadap rendemen kitin yang dihasilkan. Dari uji coba skala pilot plant ini dapat disimpulkan bahwa proses deproteinasi cangkang rajungan yang paling optimal adalah dengan menggunakan larutan $\mathrm{NaOH}$ teknis 3,5\% selama 2 jam. Rendemen kitin yang dihasilkan cukup tinggi $(13,3 \%)$ dan mutunya sesuai dengan standar yang berlaku di pasar internasional.
\end{abstract}

\begin{abstract}
Pilot scale chitin production from crab (Portunus spp.) shell. By: Sumpeno Putro, Syamdidi, and Singgih Wibowo

Studies on pilot scale chitin production from crab shell have been carried out. The studies were intended to reveal the optimum sodium hydroxide concentration and extraction time for chitin production from waste of crab shells. Previous studies showed that sodium hydroxide solution was found to be very effective and efficient chemical to remove the protein portion from crab shell prior to decalcification process. For pilot scale production, the use of technical grade chemical is needed due to the lower price compared to the analytical grade. However, since the low purity of the technical grade chemical, studies have to be conducted to confirm the appropriate concentration needed, as to get the best quality product at the lowest cost. Based on previous research result that the best concentration of sodium hydroxide is $3 \%$, this studies designed to use $3.5 \%, 5 \%$, and $6.5 \%$ with soaking time of 2 and 3 hours. Results of the studies showed that for deproteination purposes, the use of $3.5 \%, 5 \%$ and $6.5 \%$ of sodium hydroxide solution as well as soaking of crab shells in the above sodium hydroxide solutions for 2 and 3 hours, showed no significant difference on the yield of chitin. It can be concluded that soaking of crab shells in 3.5\% sodium hydroxide solution for 2 hours gave the best yield (13.3\%) and able to produce high yield and good quality of chitin which comply with the prevailing international standards.
\end{abstract}

KEYWORDS: chitin, crab shell, pilot plant

\section{PENDAHULUAN}

Kitin merupakan biopolimer terbanyak kedua setelah selulosa, jumlahnya berlimpah dan banyak tersebar di alam. Kitin banyak ditemukan pada serangga, mikroorganisme, kepala dan kulit hewan kelompok avertebrata berkulit keras seperti udang, kepiting, tiram, dan cumi-cumi. Kitin termasuk senyawa organik penting yang banyak berfungsi sebagai penyusun cangkang lobster $(12 \%)$, kepiting (13\%), udang (8\%), antartic krill $(2,3-6,1 \%)$, dinding sel kapang (44\%) dan dinding sel jamur (40\%) (Knorr, 1984). Cangkang dan kulit golongan crustacea merupakan sumber kitin yang paling kaya, karena

Peneliti pada Balai Besar Riset Pengolahan Produk dan Bioteknologi Kelautan dan Perikanan, DKP 
kandungan kitinnya dapat mencapai 40-60\% (bobot kering). Kitin juga dapat disintesis dari beberapa substrat gula nukleotida, seperti uridin diphospho-Nasetilglukosamin dengan menggunakan enzim kitin sintetase (Sanford, 2003 dalam Zilda et al., 2006).

Indonesia sebagai salah satu negara produsen/ pengekspor udang dan rajungan terbesar di dunia, mempunyai potensi yang sangat besar untuk mengembangkan industri pengolahan limbah udang dan rajungan menjadi kitin dan kitosan. Pengolahan limbah udang dan rajungan menjadi kitin dan kitosan, selain akan membantu mengatasi masalah pencemaran lingkungan, juga akan mampu meningkatkan nilai tambah dan keuntungan perusahaan. Hal ini mengingat bahwa limbah industri udang dan rajungan pada umumnya menjadi beban bagi perusahaan terutama terkait dengan masalah AMDAL. Di samping itu, harga limbah di pasaran ratarata berkisar antara Rp. 2.000 sampai Rp. $2.500 / \mathrm{kg}$. Apabila limbah ini diolah menjadi kitin, harga jualnya akan meningkat menjadi lebih dari Rp. $15.000 / \mathrm{kg}$ dan bila diolah lebih lanjut menjadi kitosan, harganya akan meningkat minimal $8 \mathrm{USD} / \mathrm{kg}$.

Limbah industri udang dan rajungan pada umumnya terdiri dari protein, kitin dan kalsium. Hasil penelitian terdahulu menunjukkan bahwa dalam skala laboratorium, pemanfaatan limbah kulit udang dan cangkang rajungan menjadi kitin dan kitosan mempunyai prospek yang sangat baik untuk dikembangkan. Beberapa masalah teknis seperti proses pemisahan protein (deproteinasi) menggunakan $\mathrm{NaOH}$, pemisahan kalsium (demineralisasi) maupun deasetilasi telah dapat diatasi, serta mampu menghasilkan rendemen kitin dan kitosan yang tinggi dengan mutu yang sesuai dengan standar internasional. Saleh et al. (1994) menyatakan bahwa pada skala laboratorium, untuk pembuatan kitin dari kulit udang diperlukan $\mathrm{NaOH}$ p.a. (pro analysis grade) dengan konsentrasi $3 \%$. Pada skala produksi besar, penggunaan bahan kimia p.a. tidak memungkinkan karena harganya sangat mahal.

Penelitian ini dimaksudkan untuk mengkonfirmasi konsentrasi $\mathrm{NaOH}$ teknis yang paling optimal dalam proses deproteinasi ekstraksi kitin dalam skala pilot plant, karena bahan kimia teknis (technical grade) mempunyai kemurnian yang rendah. Penelitian ini merupakan rangkaian dari kegiatan pemantapan prosedur ekstraksi kitin dan kitosan dalam rangka scaling up produksi dari skala laboratorium menjadi skala pilot plant. Dari penelitian ini diharapkan diperoleh konsentrasi $\mathrm{NaOH}$ yang optimal, sehingga proses deproteinasi dapat berjalan sempurna dan penggunaan $\mathrm{NaOH}$ lebih efisien. Hal ini mengingat bahwa $\mathrm{NaOH}$ merupakan bahan kimia yang cukup mahal dan paling banyak digunakan dalam industri pengolahan kitin dan kitosan. Apabila penggunaan $\mathrm{NaOH}$ dapat ditekan dan lebih efisien, maka harga jual kitin maupun kitosan yang dihasilkan akan menjadi lebih kompetitif sehingga mampu bersaing dengan produk sejenis dari negara-negara pesaing khususnya China. Seperti diketahui bahwa harga jual kitosan rata-rata di pasar internasional berkisar antara 12-15 USD/kg; sedang kitosan produksi China harganya hanya $7-8 \mathrm{USD} / \mathrm{kg}$. Data dari hasil penelitian ini sangat dibutuhkan untuk skala industri karena dapat meningkatkan efisiensi usaha dan mengurangi biaya yang terbuang sia-sia akibat penggunaan $\mathrm{NaOH}$ berlebih.

\section{BAHAN DAN METODE}

Bahan baku yang digunakan dalam penelitian ini adalah cangkang rajungan kering. Cangkang rajungan yang digunakan adalah cangkang kaki besar (capit) yang diperoleh dari miniplan pengolahan rajungan di Cirebon Jawa Barat. Jumlah cangkang yang digunakan untuk tiap perlakuan sebanyak $2 \mathrm{~kg}$ (berat kering).

Proses produksi kitin dilakukan berdasarkan modifikasi dari metode Gates, (1991); Chen et al. (1997); Wibowo, (2003); Dwiyitno et al. (2004); Oktavia et al. (2005). Sebanyak $2 \mathrm{~kg}$ capit rajungan kering dimasukkan ke dalam tangki ekstraksi stainless steel yang telah di isi larutan $\mathrm{NaOH}$ teknis dengan suhu $70-80^{\circ} \mathrm{C}$. Perbandingan capit rajungan dan larutan adalah $1: 15(\mathrm{~b} / \mathrm{v})$ dengan variasi konsentrasi $\mathrm{NaOH}$ 3,5\%; $5 \%$; dan 6,5\%. Setelah dimasukkan ke dalam tangki ekstraksi, capit diaduk secara merata setiap 30 menit untuk memastikan semua capit terendam dalam Iarutan $\mathrm{NaOH}$. Proses ekstraksi dilakukan dengan 2 variasi waktu yaitu 2 dan 3 jam.

Setelah proses ekstraksi selesai, capit dicuci dengan air sampai netral lalu dilakukan proses demineralisasi. Cangkang rajungan yang sudah netral tadi kemudian langsung dimasukkan ke dalam tangki stainless steel berisi larutan $\mathrm{HCl} 10 \%$ dan direndam selama 2 jam. Rasio cangkang kering dan $\mathrm{HCl}$ yang digunakan yaitu $1: 1,5(\mathrm{~b} / \mathrm{v})$. Setelah proses demineralisasi selesai, cangkang dicuci bersih sampai netral lalu dikeringkan di bawah sinar matahari. Untuk mendapatkan kitin dengan tingkat kekeringan cukup, proses pengeringan yang dibutuhkan adalah kurang lebih 2 hari.

Analisis yang dilakukan terhadap kitin yang dihasilkan meliputi rendemen, kadar air, kadar abu dan kadar protein (AOAC, 1999). Percobaan didesain menggunakan rancangan acak lengkap dengan tiga ulangan. 


\section{HASIL DAN BAHASAN}

\section{Kadar Air}

Kadar air merupakan parameter yang penting untuk menentukan mutu kitin. Kadar air yang rendah menentukan daya awet dari produk selama penyimpanan. Standar mutu untuk kadar air pada kitin menurut Protan Lab. (1987) dalam Setyahadi, 2006 adalah sebesar $\leq 10 \%$. Berdasarkan hasil analisis, kadar air kitin yang dihasilkan pada penelitian ini berkisar antara $3,81-4,56 \%$. Kadar air tertinggi diperoleh pada perlakuan $\mathrm{NaOH} 5 \%$ selama 2 jam yaitu sebesar $4,56 \%$ dan yang paling rendah pada perlakuan $\mathrm{NaOH} 3,50 \%$ selama 3 jam. Hasil penelitian ini menunjukkan bahwa kadar air dari kitin yang dihasilkan sudah memenuhi standar mutu produk kitin yang diterima di pasar.

Beberapa faktor yang berperan penting terhadap kadar air pada kitin yaitu proses pengeringan, lama pengeringan, jumlah kitin yang dikeringkan serta luas tempat pengeringan (Saleh et al., 1994). Kadar air kitin tidak dipengaruhi oleh jumlah bahan, nisbah dan waktu proses tetapi dipengaruhi oleh waktu pengeringan terhadap kitin yang dihasilkan. Menurut Hong et al. (1989) semakin murni kitin yang dihasilkan maka akan semakin kuat untuk mengikat air.
Hasil penelitian ini menunjukkan bahwa nilai kadar air dipengaruhi oleh waktu ekstraksi tetapi tidak dipengaruhi oleh konsentrasi $\mathrm{NaOH}$. Semakin lama waktu ekstraksi, nilai kadar air semakin menurun.

\section{Kadar Abu}

Dari hasil penelitian ini dapat dilihat bahwa kadar abu kitin untuk semua perlakuan berkisar antara $0,24 \%-0,35 \%$, dan masih berada di bawah standar yang ditetapkan oleh Protan Biopolimer yaitu di bawah 2\% (Bustaman, 1989). Berdasarkan hasil analisis dapat dilihat bahwa perlakuan peningkatan konsentrasi $\mathrm{NaOH}$ dan waktu ekstraksi memberikan hasil yang berbeda terhadap kadar abu yang dihasilkan. Hal ini diduga karena adanya reaksi $\mathrm{NaOH}$ dengan protein pada permukaan cangkang sehingga lapisan protein pada cangkang menjadi terkelupas dan memudahkan penetrasi $\mathrm{HCl}$ ke dalam cangkang. Terkelupasnya lapisan protein dari cangkang ini menyebabkan reaksi antara $\mathrm{HCl}$ dengan senyawa mineral lebih sempurna sehingga proses demineralisasi menjadi lebih efektif.

Berdasarkan pengamatan visual pada saat penelitian, semakin tinggi konsentrasi $\mathrm{NaOH}$ yang digunakan, proses demineralisasi berlangsung lebih sempurna. Hal ini ditandai dengan banyaknya jumlah buih yang dihasilkan pada proses demineralisasi. Semakin tinggi jumlah $\mathrm{NaOH}$ yang digunakan,

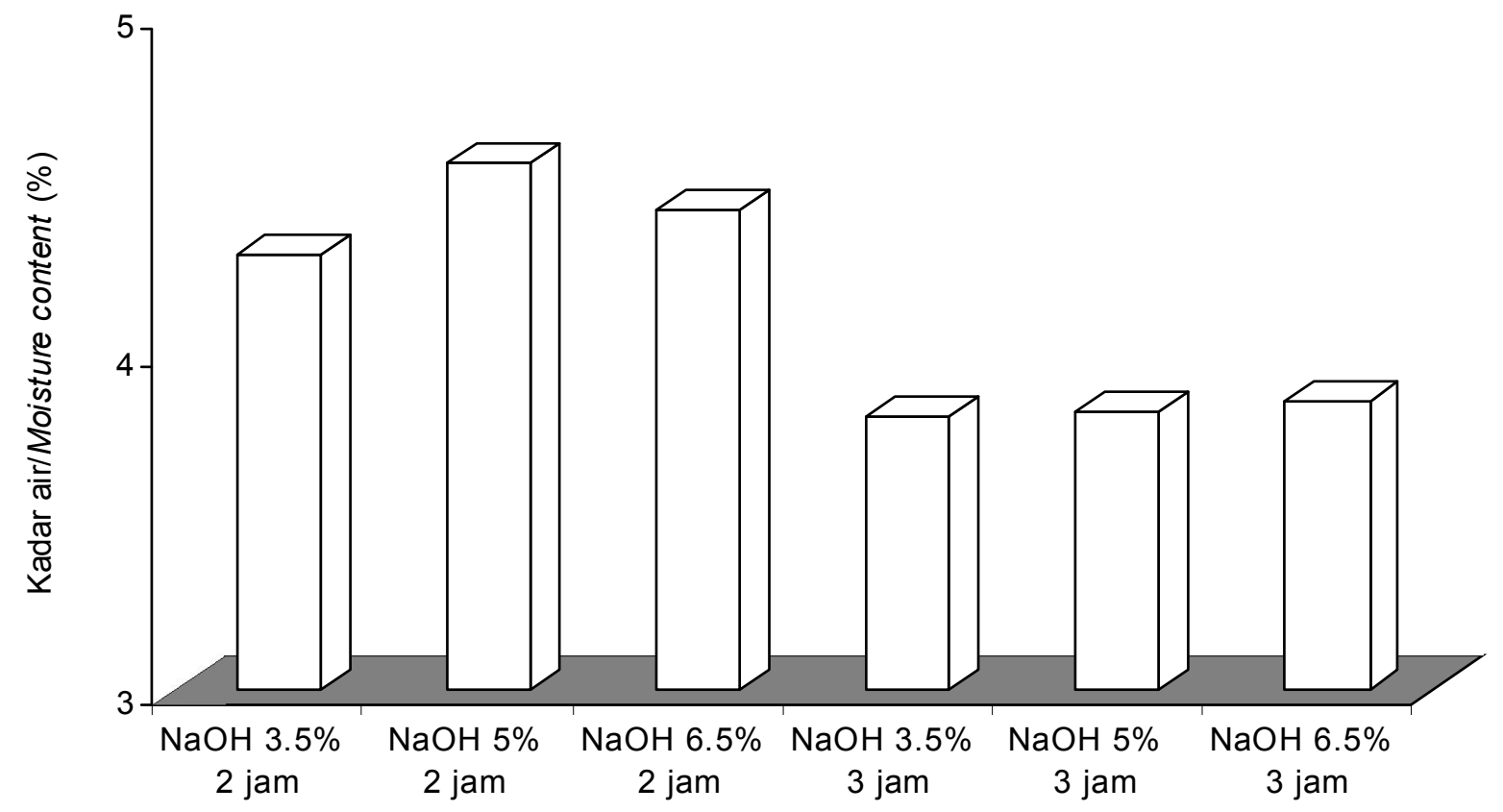

Gambar 1. Kadar air kitin dengan berbagai konsentrasi $\mathrm{NaOH}$ dan waktu ekstraksi.

Figure 1. The effects of sodium hydroxide concentration and extraction time on the moisture content of chitin. 


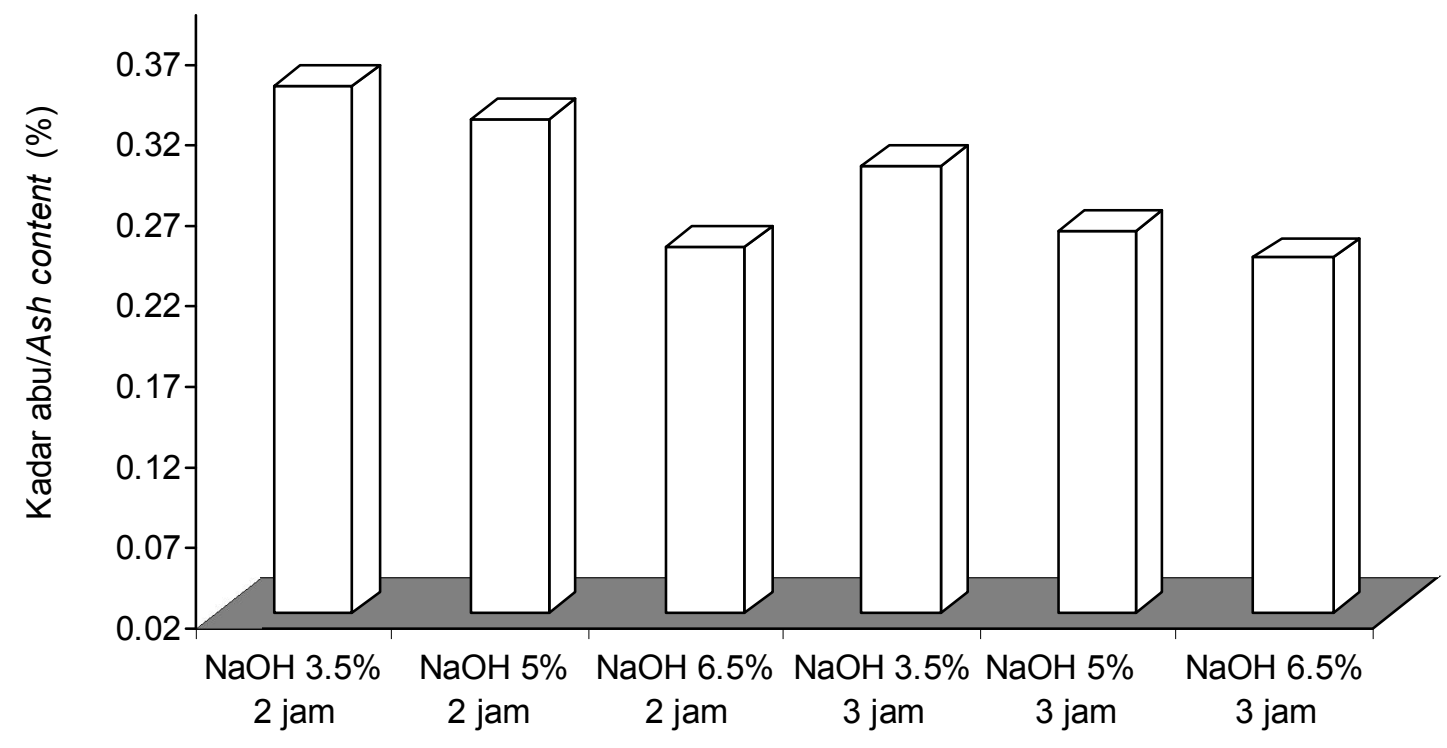

Gambar 2. Kadar abu kitin dengan berbagai konsentrasi $\mathrm{NaOH}$ dan waktu ekstraksi.

Figure 2. The effects of sodium hydroxyde concentration and extraction time on the ash content of chitin.

efektitivitas senyawa $\mathrm{HCl}$ untuk bereaksi dengan senyawa mineral pada cangkang lebih sempurna. Efektivitas senyawa $\mathrm{HCl}$ pada proses demineralisasi juga berkolerasi dengan waktu ekstraksi pada proses deproteinasi. Penambahan waktu ekstraksi memberikan hasil yang berbeda terhadap kadar abu kitin.

\section{Kadar Protein}

Proses deproteinasi bertujuan untuk mereduksi protein yang terdapat dalam bahan. Dari hasil penelitian, kandungan protein kitin semakin menurun seiring dengan meningkatnya konsentrasi $\mathrm{NaOH}$ yang digunakan akan tetapi penambahan waktu ekstraksi

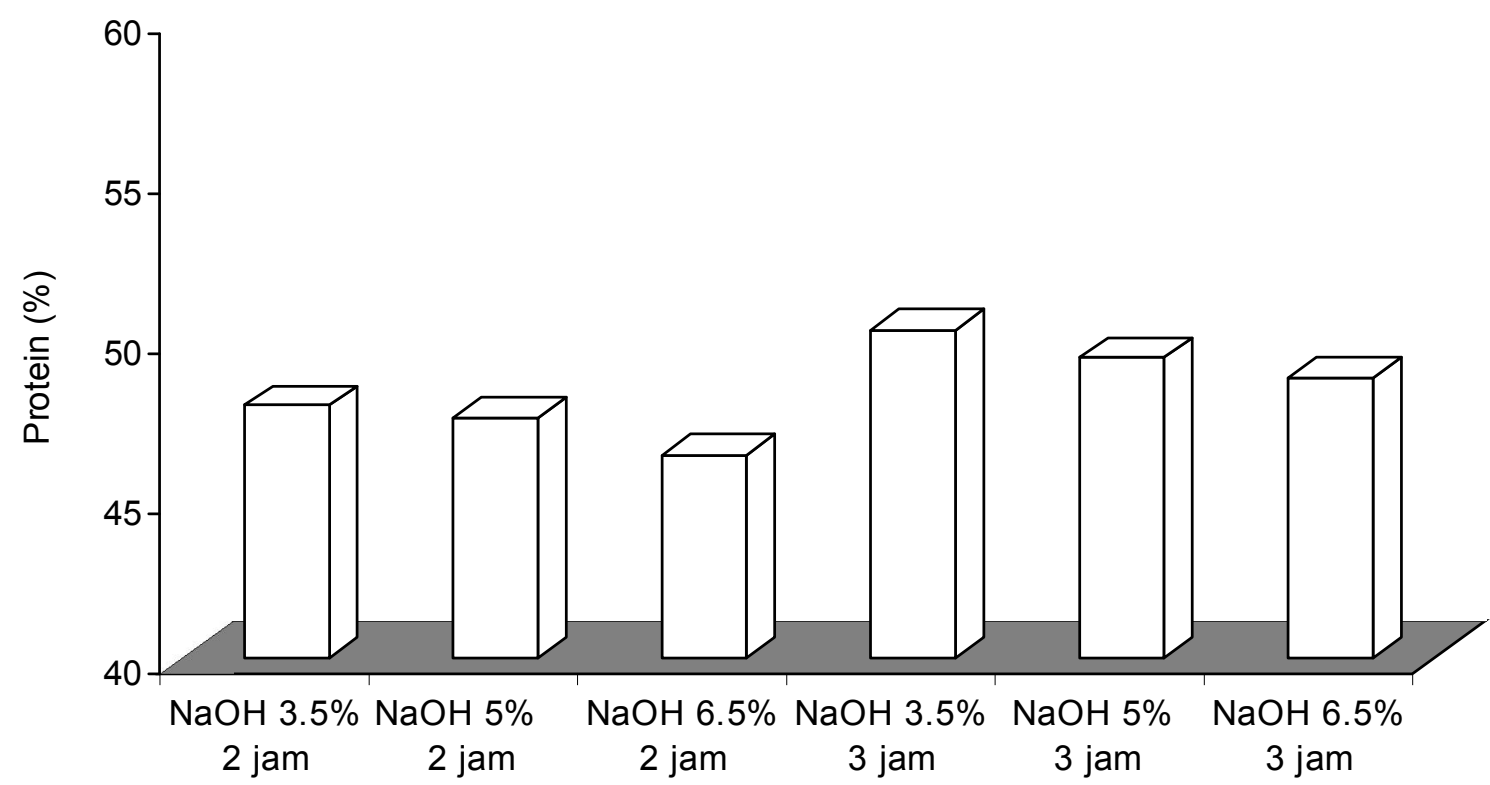

Gambar 3. Kadar protein kitin dengan berbagai konsentrasi $\mathrm{NaOH}$ dan waktu ekstraksi.

Figure 3. The effects of sodium hydroxyde concentration and extraction time on the protein content of chitin. 
dari 2 jam menjadi 3 jam tidak memberikan perbedaan yang nyata terhadap penurunan kandungan protein kitin.

Hasil penelitian menunjukkan bahwa semakin meningkatnya konsentrasi $\mathrm{NaOH}$ maupun waktu perendaman tidak berpengaruh signifikan terhadap kandungan protein pada cangkang rajungan, meskipun menurut Saleh et al. (1994), kadar protein dipengaruhi oleh konsentrasi $\mathrm{NaOH}$ yang digunakan. Semakin tinggi konsentrasi $\mathrm{NaOH}$ yang digunakan, semakin sempurna reaksi antara protein dengan $\mathrm{NaOH}$ membentuk ester, sehingga protein yang dapat dihilangkan dari cangkang akan semakin banyak.

\section{Rendemen}

Kadar rendemen suatu bahan biasanya berkorelasi dengan bahan-bahan penyusunnya. Semakin banyak unsur penyusunnya hilang pada waktu proses maupun pencucian maka kadar rendemennya akan menurun. Pada penelitian ini, terdapat dua tahapan proses yang menyebabkan terjadinya penghilangan komponenkomponen penyusun senyawa kitin. Tahap pertama adalah proses deproteinasi yang menyebabkan hilangnya sebagian protein dan tahap kedua proses demineralisasi yang menyebabkan hilangnya senyawa mineral dan kapur. Menurut Bustaman (1989), pada proses demineralisasi akan terjadi pembentukan kalsium klorida, asam karbonat dan asam fosfat yang larut air yang akan terbuang pada saat pencucian.

Hilangnya komponen-komponen penyusun pada dua tahapan proses ektraksi kitin akan mempengaruhi jumlah rendemen yang dihasilkan. Nilai rendemen kitin pada penelitian ini menunjukkan kecenderungan menurun sesuai dengan bertambahnya waktu ekstraksi dan konsentrasi $\mathrm{NaOH}$ yang digunakan. Nilai rendemen kitin ini juga berkolerasi positif dengan kadar abu dan kadar protein kitin. Semakin tinggi kadar abu dan kadar protein kitin, nilai rendemen kitin juga akan meningkat. Perlakuan ekstraksi $\mathrm{NaOH} 3,5 \%$ selama 2 jam menghasilkan rendemen paling tinggi yaitu sebesar $13,3 \%$ sedangkan rendemen paling rendah diperoleh pada perlakuan ekstraksi $\mathrm{NaOH} 6,5 \%$ selama 3 jam yaitu sebesar $12,2 \%$.

Selain itu, rendemen yang bervariasi antar perlakuan bisa juga disebabkan karena kekurang hatihatian dalam proses demineralisasi dan deproteinasi terutama pada tahap pemisahan dan pencucian. Hal ini disebabkan karena pada saat pencucian, remahremahan cangkang akibat pengadukan lolos dari keranjang pencucian sehingga ikut terbuang. Untuk mengatasi masalah ini maka keranjang yang digunakan untuk pencucian harus memiliki ukuran lubang yang cukup kecil.

\section{KESIMPULAN DAN SARAN}

1. Ekstraksi kitin menggunakan $\mathrm{NaOH}$ teknis sebesar $3,5 \%, 5 \%$ dan $6,5 \%$ selama 2 dan 3 jam mampu menghasilkan kitin dengan kualitas kadar abu dan kadar air sesuai dengan standar yang berlaku di pasar internasional.

2. Penambahan waktu ekstraksi dari 2 menjadi 3 jam tidak memberikan perbedaan yang nyata terhadap penurunan kandungan protein kitin.

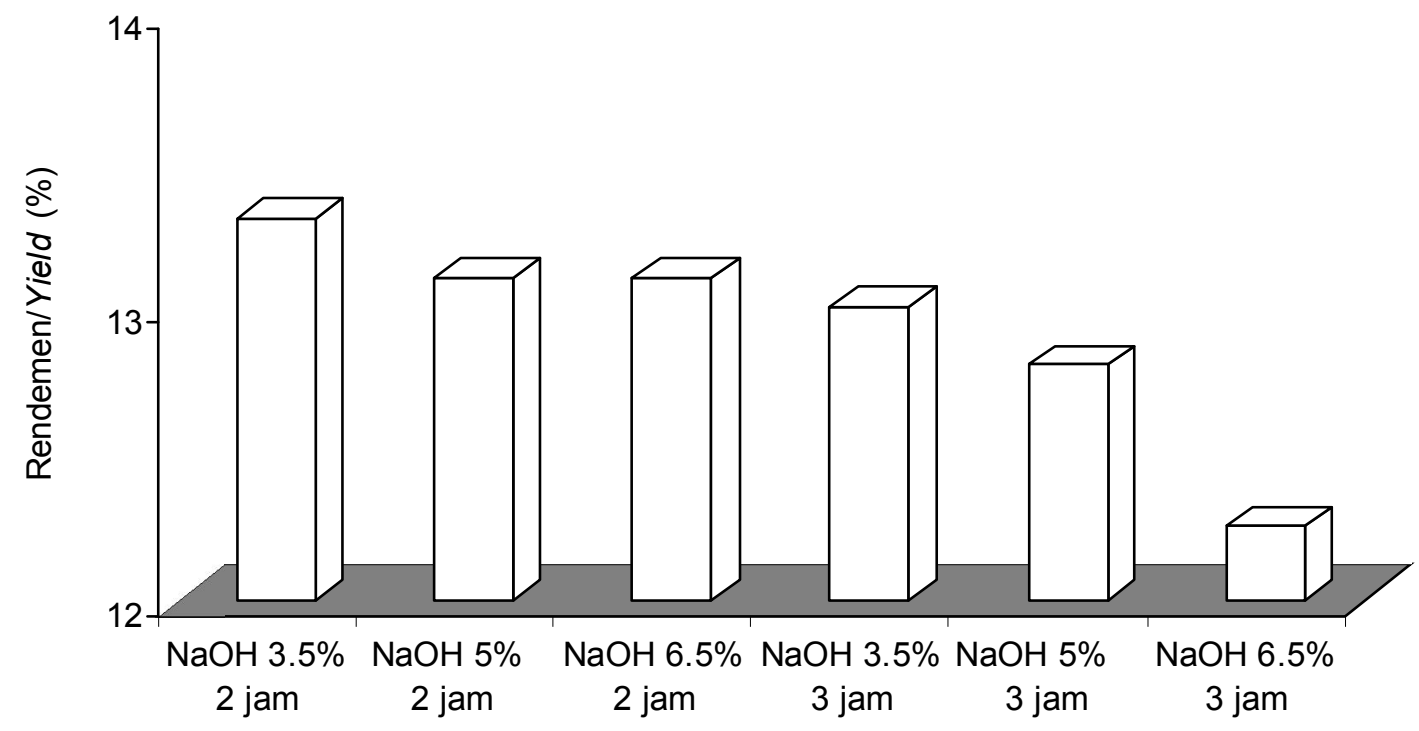

Gambar 4. Rendemen kitin dengan berbagai konsentrasi $\mathrm{NaOH}$ dan waktu ekstraksi. Figure 4. Yield of chitin using various $\mathrm{NaOH}$ concentration and extraction time. 
3. Untuk aplikasi dalam industri kitin skala komersial, ekstraksi kitin menggunakan $\mathrm{NaOH}$ teknis pada konsentrasi 3,5\% selama 2 jam adalah paling optimal dan mampu menghasilkan kitin sesuai dengan standar mutu yang telah ditetapkan oleh pasar internasional.

\section{DAFTAR PUSTAKA}

AOAC. 1999. Official Methods of Analysis. $13^{\text {rd }}$ ed. Association of Official Analytical Chemists. Washington D.C.

Bustaman, S. 1989. Studies on Degradation and Extraction of Chitin and Chitosan from Prawn Shells. Thesis. The Department of Mechanical. Manufacturing Aeronautical and Chemical Engineering. The Queen's University. Belfast. 204 pp.

Chen, Rong-Huei., Chang, Jaan-Rong, and Shyur, JuShii. 1997. Effects on ultrasonic conditions and storage in acidic solutions on changes in molecular weight and polydispersity of treated chitosan. Carbohydrate Research. 299: 287-294.

Dwiyitno, Basmal, J. dan Mulyasari. 2004. Pengaruh suhu esterifikasi terhadap karakteristik karboksimetil kitosan (CMCts). J. Penel. Perik. Indonesia. Edisi Pasca Panen. 10(3): 67-73.

Gates, KW. 1991. Waste reduction, water conservation and recovery of seafood by products. Marine Technol Soc J. 25: 44-51

Hong, H., No. K., Meyers, S.P. and Lee, K.S. 1989. Isolation and characterization of chitin from crawfish shell waste. J. Agric. Food Chem. 37(3): 575-578.
Knorr, D. 1984. Uses of chitinous polymer in food - A challenge for food research and development (chitin, chitosan, functional properties, nutritional aspects, safety). Food Technol. 38(1): 85-89, 92-97.

Oktavia, D.A., Wibowo, S., dan Fawzya, Y.N. 2005. Pengaruh jumlah monokloro asetat terhadap karakteristik karboksimetil kitosan dari kitosan cangkang dan kaki rajungan. J. Penel. Perik. Indonesia. Edisi Pasca Panen. 11(4): 79-88.

Saleh, M., Abdilla, R., Suherman, M., Basmal, J. dan Indriati, N. 1994. Pengaruh suhu, waktu dan konsentrasi pelarut pada ekstraksi kitosan dari limbah pengolahan udang beku terhadap beberapa parameter mutu kitosan. Jurnal Pasca Panen Perikanan. 81: 30-39.

Setyahadi, S. 2006. Pengembangan produksi kitin secara mikrobiologi. Prosiding Seminar Nasional Kitin-Kitosan 2006. In Santoso, J., Trilaksanai, W., Nurhayati, T., dan Suseno, S.H. (eds.). Departemen Teknologi Hasil Perairan - FPIK, IPB. Bogor. p. 3340

Wibowo, S. 2003. Surimi Wash Water Treatment by Chitosan-Alginate Complexes: Effect of Molecular Weight and Degree of Deacetylation of Chitosan and Nutritional Evaluation of Solids Recovered by the Treatment. PhD Disertation. Department of Food Science and Technology, Oregon State University, Corvallis, Orgeon, USA.

Zilda, D.S., Fawzya, Y.N., dan Chasanah, E. 2006. Karakterisasi enzim kitosanase dari bakteri kitinolitik T5a1 yang diisolasi dari terasi. Jurnal Pascapanen dan Bioteknologi Kelautan dan Perikanan. Badan Riset Kelautan dan Perikanan. 1(1): 43-49. 